\title{
Effects of ischemic pre- and postconditioning on HIF- $1 \alpha$, VEGF and TGF- $\beta$ expression after warm ischemia and reperfusion in the rat liver
}

\author{
Anders R Knudsen 1*, Anne-Sofie Kannerup', Henning Grønbæk³, Kasper J Andersen', Peter Funch-Jensen', \\ Jan Frystyk ${ }^{2}$, Allan Flyvbjerg ${ }^{2}$ and Frank $V$ Mortensen ${ }^{1}$
}

\begin{abstract}
Background: Ischemic pre- and postconditioning protects the liver against ischemia/reperfusion injuries. The aim of the present study was to examine how ischemic pre- and postconditioning affects gene expression of hypoxia inducible factor $1 \alpha(H I F-1 \alpha)$, vascular endothelial growth factor A (VEGF-A) and transforming growth factor $\beta$ (TGF$\beta$ ) in liver tissue.
\end{abstract}

Methods: 28 rats were randomized into five groups: control; ischemia/reperfusion; ischemic preconditioning (IPC); ischemic postconditioning (IPO); combined IPC and IPO. IPC consisted of $10 \mathrm{~min}$ of ischemia and $10 \mathrm{~min}$ of reperfusion. IPO consisted of three cycles of $30 \mathrm{sec}$. reperfusion and $30 \mathrm{sec}$. of ischemia.

Results: HIF-1 $\alpha$ mRNA expression was significantly increased after liver ischemia compared to controls ( $p=0.010)$. HIF-1 $\alpha$ mRNA expression was significantly lower in groups subjected to IPC or combined IPC and IPO when compared to the ischemia/reperfusion group $(p=0.002)$. VEGF-A mRNA expression increased in the ischemia/ reperfusion or combined IPC and IPO groups when compared to the control group ( $p<0.05)$.

Conclusion: Ischemic conditioning seems to prevent HIF-1 $\alpha$ mRNA induction in the rat liver after ischemia and reperfusion. This suggests that the protective effects of ischemic conditioning do not involve the HIF-1 system. On the other hand, the magnitude of the HIF-1 $\alpha$ response might be a marker for the degree of I/R injuries after liver ischemia. Further studies are needed to clarify this issue.

\section{Background}

Colorectal cancer is a leading form of cancer in the Western world. Approximately $50 \%$ of patients with this disease have, or will eventually develop, liver metastases. Surgical removal of those metastases remains the treatment of choice, with a five year survival rate of $37 \%$ $58 \%$ after resection [1-3]. Major hemorrhage and blood transfusion during liver resection is related to an increase in morbidity and mortality [4-6]. Vascular clamping is a frequently used method for reducing blood loss [7]. Several studies have shown that the normal livers tolerate periods of continuous warm ischemia

\footnotetext{
* Correspondence: auknudsen@gmail.com

'Department of Surgical Gastroenterology L, Aarhus University Hospital, Aarhus, Denmark

Full list of author information is available at the end of the article
}

up to $90 \mathrm{~min}$ and intermittent warm ischemia up to 120 $\min [8-10]$.

However, ischemia/reperfusion (I/R) injury of the liver is an unfortunate side effect of this method, ranging from slightly elevated liver enzymes to acute liver failure [11]. Ischemic pre- or postconditioning (IPC or IPO), defined as brief periods of ischemia and reperfusion before or after sustained ischemia, have proven to increase the ability of organs to tolerate $I / R$ injury [12-16]. The precise mechanisms responsible for the hepatoprotection from ischemic injuries are only partially known. Focus has been on a system of hypoxia inducible factors (HIF), where especially HIF-1 appears to have a major role in cellular adaptation to hypoxia. HIF-1 mediates essential homeostatic responses to cellular hypoxia by up-regulating gene transcription, via specific DNA motif called hypoxia response elements, and

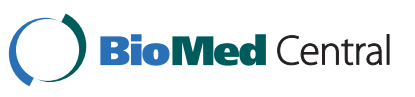


activating target genes. HIF-1 is a heterodimer protein consisting of an $\alpha$ and $\beta$-subunit. The $\beta$-subunit is expressed ubiquitously in most cells, whereas expression of the $\alpha$-subunit is controlled by cellular oxygen tension. Under normal conditions the HIF-1 $\alpha$ protein is degraded via an oxygen dependent system. By contrast, hypoxia inactivates the degradation causing stabilization of the HIF- $1 \alpha$ protein, which then translocate to the nucleus and forms dimers with the $\beta$-subunit [17]. The active form of HIF-1 transactivates other genes as vascular endothelial growth factor (VEGF) and transforming growth factor $\beta 1$ (TGF- $\beta 1$ ) $[18,19]$. VEGF is an important growth factor involved in angiogenesis. It is a multifunctional protein, with several effects on endothelial cells to promote the formation of new vessels. Furthermore, it stimulates the production of hepatocyte growth factor (HGF), which is regarded as an initiator of liver regeneration [20]. TGF- $\beta 1$ is a member of the superfamily of cytokines. In the liver, TGF- $\beta 1$ has anti-inflammatory properties and stimulates cell proliferation as well as differentiation [20].

Besides I/R injuries, another possible drawback of liver ischemia in cancer surgery could be growth stimulation of micrometastases. Several studies indicate that the outgrowth of micrometastases is stimulated by $I / R$ injuries during hepatic resections [21-23]. Outgrowth of these micro metastases may at least in part, be stimulated by an increased HIF-1 $\alpha$ stabilization [22]. As mentioned above, HIF-1 $\alpha$ activates other genes such as VEGF and TGF- $\beta$. Especially VEGF is an important growth factor involved in angiogenesis [24-26]. In this sense a stimulation of HIF-1 $\alpha$, via liver ischemia, could be a doubleedged sword; i.e., it protects the liver against I/R injuries, but a side effect could be the growth stimulation of micrometastases through angiogenesis.

The aim of the present study was to examine how ischemia, with or without IPC and IPO, affects the expression of HIF- $1 \alpha$ and the target genes VEGF and TGF- $\beta 1$, in rodent liver.

\section{Methods}

The surgical and experimental protocols were approved by the Danish Animal Research Committee, Copenhagen, Denmark according to license number 2007/5611311 and followed the Guide for the Care and Use of Laboratory Animals published by the National Institute of Health. Twenty-eight adult male Wistar rats weighing 300-350 g (M\&B Taconic, Eiby, Denmark) were used for the experiment. Animals were housed in standard animal laboratories with a temperature maintained at $23^{\circ} \mathrm{C}$ and an artificial 12-hour light-dark cycle, with food and water ad libitum, until the time of the experiment. The rats were randomly divided into five groups as follows: sham operated control (CG) $(n=4)$; pure ischemia and reperfusion (IRI) $(n=6)$; IPC $(n=6)$; IPO $(n=6)$; and IPC+IPO $(n=6)$ (Figure 1$)$. All animals were anaesthetized with $0.75 \mathrm{ml} / \mathrm{kg}$ Hypnorm s.c. (Fentanyl/Fluanisone, Jansen Pharma, Birkerød, Denmark) and $4 \mathrm{mg} / \mathrm{kg}$ Midazolam s.c. (Dormicum, La Roche, Basel, Switzerland) and placed on a heated pad. A midline laparotomy was performed and total hepatic ischemia was accomplished using a microvascular clamp placed on the hepatoduodenal ligament, i.e., performing the Pringle maneuver. Reflow was initiated by removal of the clamp. Discoloration of the liver was used as a positive marker for hepatic ischemia. Reperfusion was ascertained by the return of the normal brown/reddish color of the liver. The experimental protocol was performed as described in Figure 1. At the end of each experiment after $30 \mathrm{~min}$ of reperfusion, a biopsy was taken from the right liver lobe, immediately frozen in liquid nitrogen and stored at $-80^{\circ} \mathrm{C}$ for further analysis. Blood samples were collected from the common iliac artery in tubes for measurement of alanine aminotransferase (ALAT), alkaline phosphates and bilirubin, and analyzed immediately hereafter. All rats were subsequently killed with an overdose of pentobarbital.

\section{Quantitative Real-Time PCR (RT-PCR)}

After homogenization of liver tissue by the use of a MM301 Mixer Mill (Retsch, Haan, Germany), total cellular RNA was extracted from the liver tissue using a 6100 Nucleic Acid PrepStation (Applied Biosystems, Foster City, CA, USA). The quality of rRNA was estimated by agarose gel electrophoresis by the appearance of two distinct bands visible by fluorescence of ethide

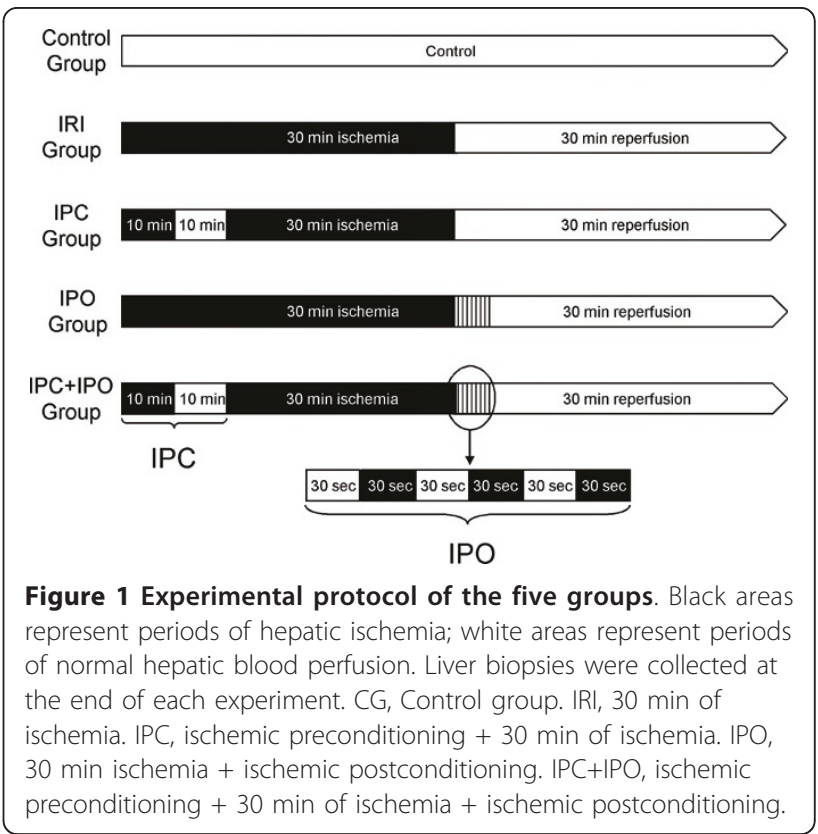


bromide representing intact rRNA. The amounts of RNA extracted were quantified by measuring the absorbance by spectrophotometry, at $260 \mathrm{~nm}$. Reverse transcription from RNA to DNA was performed with a Multiscribe Reverse Transcriptase kit from Applied Biosystem at $25^{\circ} \mathrm{C}$ for $10 \mathrm{~min}$, at $48^{\circ} \mathrm{C}$ for $30 \mathrm{~min}$ and at $94^{\circ} \mathrm{C}$ for $29 \mathrm{sec}$. The PCR was performed in triplicates of each sample in a volume of $25 \mu \mathrm{L}$ in each well containing RNA, TaqMan Universal PCR MasterMix and a primer of the target, i.e., HIF-1 $\alpha$ (Rn00577560_m1), TGF- $\beta$ (Rn00572010_m1) and VEGF-A (Rn4331348), and a primer of the housekeeping gene, 18S (4319413), all purchased from Applied Biosystems. Each RT-PCR reaction ran at $50^{\circ} \mathrm{C}$ for $2 \mathrm{~min}$, at $95^{\circ} \mathrm{C}$ for $10 \mathrm{~min}$ and in 40 cycles changing between $95^{\circ} \mathrm{C}$ for $15 \mathrm{sec}$. and $60^{\circ} \mathrm{C}$ for $1.30 \mathrm{~min}$ [27].

\section{PCR Data analysis}

Data was analyzed with the ABI Prism 7000 Sequence Detector Software from Applied Biosystems. The output of amplification was measured in the exponential phase of the reaction as the threshold cycle/Ct-value, which is defined as the cycle number at which amplification products are detected corresponding to the point where fluorescent intensity exceeds the background fluorescent intensity, which is $10 \times$ the standard deviation of the baseline. The average of triplicates from each sample was used. The relative quantification of target gene was calculated using the formula: $(1 / 2)^{\mathrm{Ct} \text {-target gene- Ct-house- }}$ keeping gene, which is described in the Users Bulletin 2, 1997 from Perkin-Elmer (Perkin-Elmer Cetus, Norwalk, CT, USA) [27].

\section{Statistical analysis}

Statistical analysis were performed by SPSS ${ }^{\circledR} 11.0$ programs (SPSS Inc., Chicago, Illinois, USA). All data is expressed as mean \pm SEM. Comparisons of data between groups were performed by non-parametric KruskalWallis (ANOVA) test followed by the Mann-Whitney $U$ test. A p value $<0.05$ was considered significant.

\section{Results}

\section{Liver parameters}

Blood samples showed a significant increase in ALAT in group IRI $(334 \pm 135 \mathrm{U} / \mathrm{L}), \operatorname{IPC}(377 \pm 104 \mathrm{U} / \mathrm{L})$, IPO $(1177 \pm 379 \mathrm{U} / \mathrm{L})$ and IPC+IPO (710 $\pm 199 \mathrm{U} / \mathrm{L})$ compared to the control group $(40 \pm 2 \mathrm{U} / \mathrm{L})$ (CG vs. IRI, IPC, IPO, and IPC+IPO, $\mathrm{p}=0.01$ ). No significant differences were found in ALAT between groups IRI, IPC, IPO and IPC+IPO. Alkaline phosphates and bilirubin were comparable between groups (Figure 2).

\section{HIF-1 $\alpha$ expression}

In the IRI group the expression of HIF- $1 \alpha$ mRNA was significantly increased after $30 \mathrm{~min}$ of reperfusion compared to the control group ( $\mathrm{p} \leq 0.01$ ). In the IPC group HIF-1 $\alpha$ mRNA expression was significantly lower than the IRI group ( $p \leq 0.01)$. In rats subjected to IPO there was a tendency towards lower HIF-1 $\alpha$ mRNA expression compared to the IRI group ( $\mathrm{p}=0.065)$. In the IPC + IPO group HIF- $1 \alpha$ mRNA expression was significantly lower compared to the IRI group (IRI vs. IPC+IPO, p $\leq$ 0.01). The HIF-1 $\alpha$ mRNA levels were comparable between group CG, IPC, IPO and IPC+IPO (Figure 3)

\section{VEGF expression}

As shown in Figure 4, VEGF mRNA expression was significantly increased in the IRI group compared to the control group ( $\mathrm{p} \leq 0.01$ ). When applying IPC+IPO VEGF mRNA expression was also increased compared to the control group ( $\mathrm{p} \leq 0.038$ ). No significant differences were observed between groups IPC, IPO and the control group (IPC vs. $\mathrm{CG}, \mathrm{p} \leq 0.067$ ) and (IPO vs. CG, $\mathrm{p} \leq 0.067$ ).

\section{TGF- $\beta 1$ expression}

No differences in TGF- $\beta 1$ mRNA expression were observed between the five groups (Figure 5).

\section{Discussion}

As expected HIF-1 $\alpha$ mRNA expression was increased significantly in rats subjected to 30 minutes of warm
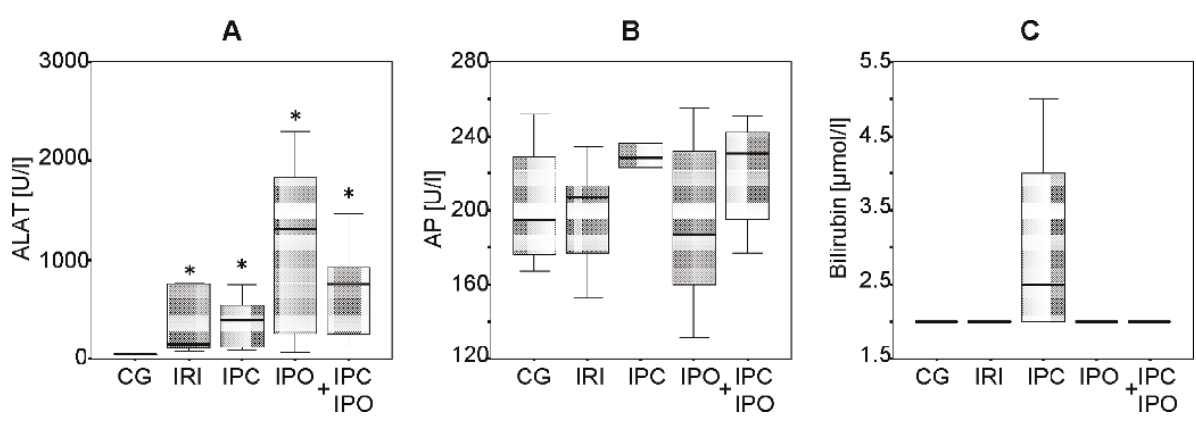

Figure 2 Blood samples including ALAT (A), alkaline phosphatase (AP) (B) and bilirubin (C) levels. Samples 30 min after reperfusion in CG, Control group. IRI, 30 min of ischemia. IPC, ischemic preconditioning + $30 \mathrm{~min}$ of ischemia. IPO, $30 \mathrm{~min}$ ischemia + ischemic postconditioning. IPC+IPO, ischemic preconditioning +30 min of ischemia + ischemic postconditioning. ${ }^{*}$ indicates $p \leq 0.01$ compared to the control group. 


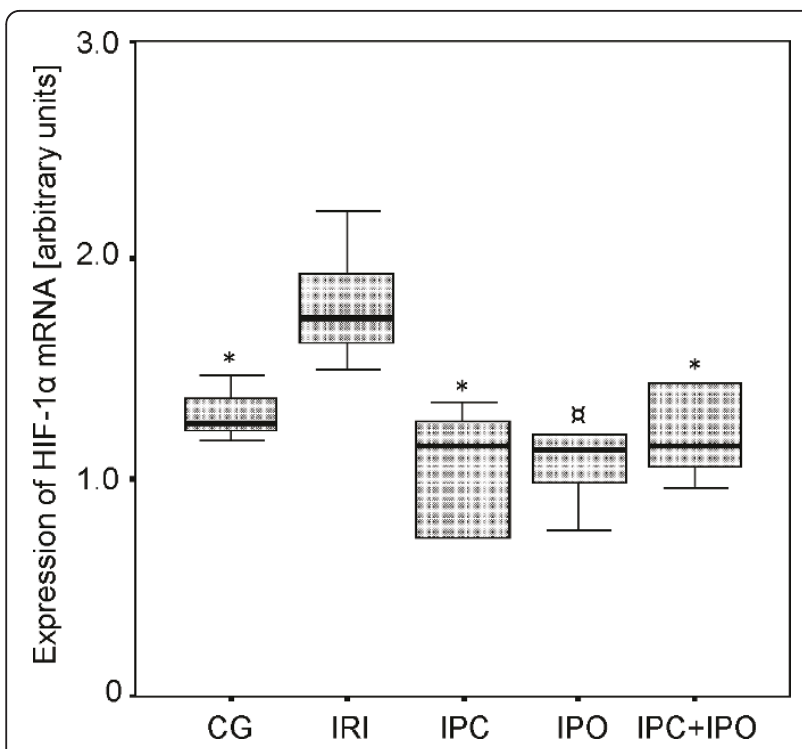

Figure 3 Expression of HIF-1 $\alpha$ mRNA. Expression after 30 min of reperfusion. CG, Control group. IRI, 30 min of ischemia. IPC, IPC + 30 min of ischemia. IPO, 30 min ischemia + IPO. IPC+IPO, IPC + 30 min of ischemia $+\mathrm{IPO} .{ }^{*}$ indicates $p \leq 0.01$ compared to group $\mid \mathrm{RI}$. $a$ indicates $p=0.065$ compared to group IRI.

liver ischemia and 30 minutes of reperfusion compared to the control group. The main finding of this study was an absent of HIF- $1 \alpha$ induction in IPC or IPC+IPO treated animals. In both of these groups, the expression levels were similar to that of CG. In the IPO group the same tendency towards an absent induction of HIF- $1 \alpha$ was observed although not significant. VEGF mRNA

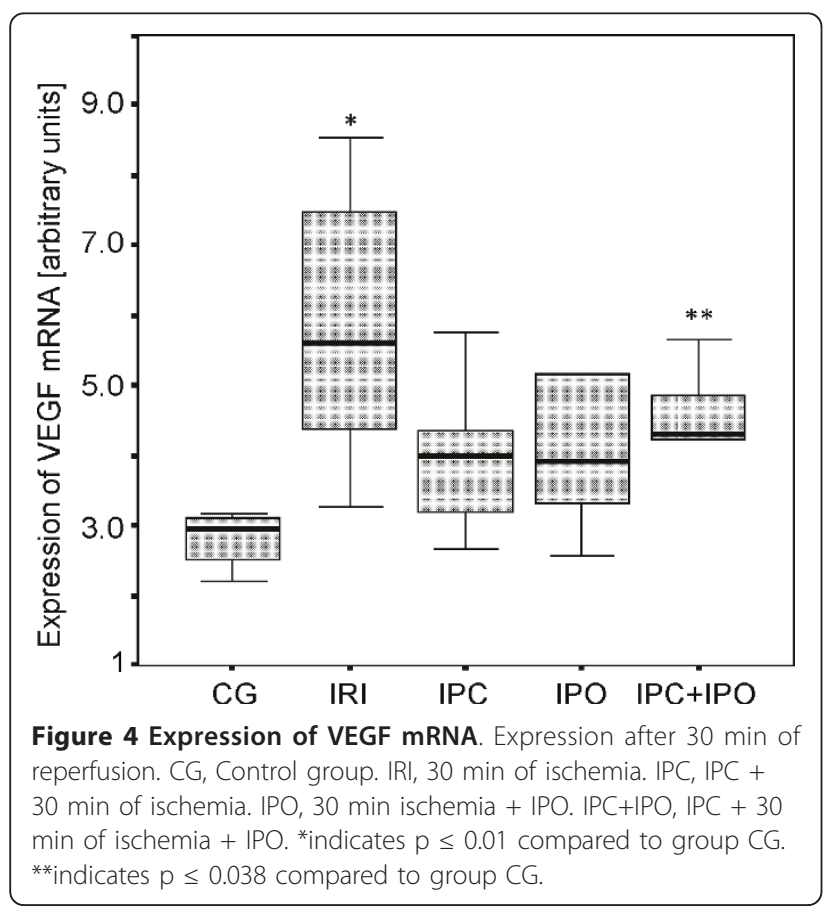

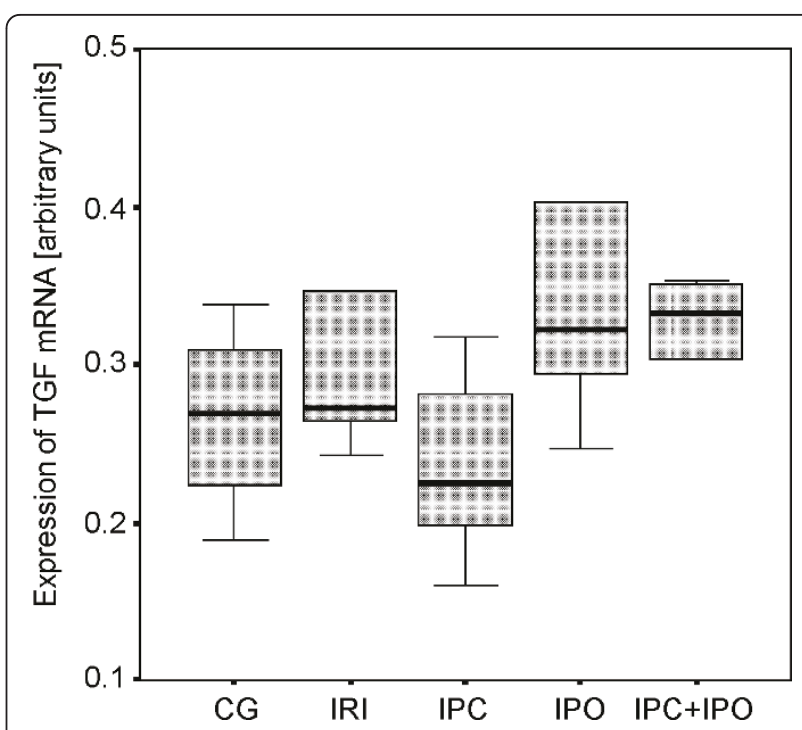

Figure $\mathbf{5}$ Expression of TGF- $\beta 1$ mRNA. Expression after 30 min of reperfusion. CG, Control group. IRI, 30 min of ischemia. IPC, IPC + 30 min of ischemia. IPO, 30 min ischemia + IPO. IPC+IPO, IPC + 30 min of ischemia + IPO

expression increased significantly when applying $30 \mathrm{~min}$ of ischemia without ischemic conditioning compared to sham operated controls. IPC+IPO also showed increased VEGF mRNA expression compared to sham operated controls, whereas neither ischemia nor ischemic conditioning affected hepatic TGF- $\beta$ expression.

The cytoprotective effects of IPC, defined as brief periods of ischemia and reperfusion prior to prolonged ischemia, on $I / R$ injuries to the liver have become indisputable with an increasing number of studies supporting this fact [12-14]. The IPC protocol used in this study has previously been shown to induce hepatoprotection against I/R injuries. We choose circulating ALAT as marker of hepacellular injuries, as this parameter is well established and known to correlate to the degree of injury [28-30]. However, we were unable to see any hepatoprotective effects as assessed by changes in liver parameters. In previous studies with the same IPC protocol, longer periods of ischemia and longer reperfusion periods were utilized $[12,14,31]$. This might explain why we were not able to demonstrate protective effects of IPC and IPO as judged by liver parameters, i.e., the duration of ischemia was too short. Furthermore, 30 min of reperfusion might be too short follow up to demonstrate the full extent of the I/R injuries. The cytoprotective effect of IPO, defined as brief periods of ischemia and reperfusion after liver ischemia, is less well established $[15,16]$. In the present study, we could not demonstrate any hepatoprotective effects of IPO assessed by liver parameters, and we speculate that the explanation may be the same as above. We choose the 
actual time protocol with 30 minutes of ischemia because we wanted to create a setting relevant for normal clinics. Even though longer periods of liver ischemia have been safely applied, most surgeons would be reluctant to induce more than 30 minutes of ischemia on the liver.

The mechanisms responsible for the protective effects of IPC and IPO are only partially understood. In the present study, IPC resulted in a significantly lower expression of HIF-1 $\alpha$ mRNA compared with rats subjected to liver ischemia without IPC. This leads us to conclude that HIF- $1 \alpha$, in our model of modest I/R-injuries, does not seem to be a mediator of the cyto-protective effects of IPC. In rats subjected to IPO there was a tendency towards lower HIF- $1 \alpha$ mRNA expression, although not significant, when compared to the sheer liver ischemia group. This indicates that HIF $1 \alpha$ is not involved in the cytoprotective effects of IPO. In this sense, the HIF-1 $\alpha$ mRNA response could to be a marker of the degree of I/R injury, i.e., the higher HIF-1 $\alpha$ mRNA response after ischemia, the more pronounced I/ $\mathrm{R}$ injuries. Further studies need to be performed to address this issue, but it is first and foremost supported in a study by Cursio et al., where they showed that the expression of HIF-1 and the degree of apoptosis was increased in rats subjected to $120 \mathrm{~min}$ of warm liver ischemia compared to non-ischemia [32]. Another study supporting the conclusion in the present paper is that by Feinman et al. [33]. They used partially HIF-1 deficient mice in a hemorrhagic shock model and concluded that HIF-1 activation was necessary for ischemic gut mucosal injury.

The expression of VEGF mRNA was regulated upwards by the ischemic episodes in the group subjected to sustained ischemia and in the IPC+IPO group. A higher expression of VEGF in the group with liver ischemia only, correlates with the elevated HIF- $1 \alpha$ expression in this group. TGF- $\beta$ expression levels were not affected in any of the groups. Both VEGF and TGF$\beta$ are, as previously described, genes that are regulated downstream of HIF- $1 \alpha$. However, as this study only focuses on the expression levels after $30 \mathrm{~min}$ of reperfusion, we cannot be sure that we are measuring the full effect of the changed HIF-1 $\alpha$ levels. If we had followed the expression levels over time, we might have seen a more direct correlation, as already reported [34].

\section{Conclusions}

Ischemic conditioning seems to prevent HIF-1 $\alpha$ mRNA induction in the rat liver after ischemia and reperfusion. This suggests that the protective effects of ischemic conditioning do not involve the HIF-1 system. On the other hand, the magnitude of the HIF-1 $\alpha$ response might be a marker for the degree of $I / R$ injuries after liver ischemia.
Further studies need to be performed to elucidate this matter.

\section{Acknowledgements}

The excellent technical assistance by Karen Mathiassen and Kirsten Nyborg is highly appreciated. The work was supported by the Health Research Fund of Central Denmark Region, Danish Medical Research Council, the Eva and Henry Frænkels Memorial Foundation and the Clinical Institute, University of Aarhus, Denmark.

\section{Author details}

'Department of Surgical Gastroenterology L, Aarhus University Hospital, Aarhus, Denmark. ${ }^{2}$ The Medical Research Laboratories, Clinical Institute, Aarhus University Hospital, Aarhus, Denmark. ${ }^{3}$ Department of Medicine V, Aarhus University Hospital, Aarhus, Denmark.

\section{Authors' contributions}

Study conception and design: ARK, A-SK, FVM. Acquisition of data: ARK, A-SK, KJA. Analysis and interpretation of data: ARK, A-SK, HG, KJA, PF-J, JF, AF, FVM. Drafting of manuscript: ARK, A-SK, KJA, FVM. Critical revision of manuscript: ARK, A-SK, HG, KJA, PF-J, JF, AF, FVM. All authors read and were in accordance with the final manuscript.

\section{Competing interests}

The authors declare that they have no competing interests.

Received: 10 January 2011 Accepted: 19 July 2011

Published: 19 July 2011

\section{References}

1. Fong $Y$, Fortner J, Sun RL, Brennan MF, Blumgart LH: Clinical score for predicting recurrence after hepatic resection for metastatic colorectal cancer: analysis of 1001 consecutive cases. AnnSurg 1999, 230:309-318.

2. Abdalla EK, Vauthey JN, Ellis LM, Ellis V, Pollock R, Broglio KR, Hess K, Curley SA: Recurrence and outcomes following hepatic resection, radiofrequency ablation, and combined resection/ablation for colorectal liver metastases. AnnSurg 2004, 239:818-825.

3. Pawlik TM, Scoggins CR, Zorzi D, Abdalla EK, Andres A, Eng C, Curley SA, Loyer EM, Muratore A, Mentha G, et al: Effect of surgical margin status on survival and site of recurrence after hepatic resection for colorectal metastases. AnnSurg 2005, 241:715-722, discussion.

4. Kooby DA, Stockman J, Ben-Porat L, Gonen M, Jarnagin WR, DeMatteo RP, Tuorto S, Wuest D, Blumgart LH, Fong Y: Influence of transfusions on perioperative and long-term outcome in patients following hepatic resection for colorectal metastases. AnnSurg 2003, 237:860-869.

5. Jarnagin WR, Gonen M, Fong Y, DeMatteo RP, Ben-Porat L, Little S, Corvera C, Weber S, Blumgart LH: Improvement in perioperative outcome after hepatic resection: analysis of 1,803 consecutive cases over the past decade. AnnSurg 2002, 236:397-406.

6. Rosen CB, Nagorney DM, Taswell HF, Helgeson SL, Ilstrup DM, van Heerden JA, Adson MA: Perioperative blood transfusion and determinants of survival after liver resection for metastatic colorectal carcinoma. AnnSurg 1992, 216:493-504.

7. van der Bilt JD, Livestro DP, Borren A, van HR, Borel Rl: European survey on the application of vascular clamping in liver surgery. Dig Surg 2007, 24:423-435.

8. Delva E, Camus Y, Nordlinger B, Hannoun L, Parc R, Deriaz H, Lienhart A, Huguet $C$ : Vascular occlusions for liver resections. Operative management and tolerance to hepatic ischemia: 142 cases. Ann Surg 1989, 209:211-218.

9. Hannoun L, Borie D, Delva E, Jones D, Vaillant JC, Nordlinger B, Parc R: Liver resection with normothermic ischaemia exceeding 1 h. Br J Surg 1993, 80:1161-1165.

10. Belghiti J, Noun R, Malafosse R, Jagot P, Sauvanet A, Pierangeli F, Marty J, Farges $\mathrm{O}$ : Continuous versus intermittent portal triad clamping for liver resection: a controlled study. AnnSurg 1999, 229:369-375.

11. Jaeschke $\mathrm{H}$ : Molecular mechanisms of hepatic ischemia-reperfusion injury and preconditioning. Am J Physiol Gastrointest Liver Physiol 2003, 284:G15-G26. 
12. Koti RS, Seifalian AM, Davidson BR: Protection of the liver by ischemic preconditioning: a review of mechanisms and clinical applications. Dig Surg 2003, 20:383-396.

13. Clavien PA, Selzner M, Rudiger HA, Graf R, Kadry Z, Rousson V, Jochum W: A prospective randomized study in 100 consecutive patients undergoing major liver resection with versus without ischemic preconditioning. Ann Surg 2003, 238:843-850.

14. Lee WY, Lee SM: Ischemic preconditioning protects post-ischemic oxidative damage to mitochondria in rat liver. Shock 2005, 24:370-375.

15. Sun K, Liu ZS, Sun Q: Role of mitochondria in cell apoptosis during hepatic ischemia-reperfusion injury and protective effect of ischemic postconditioning. World J Gastroenterol 2004, 10:1934-1938.

16. Wu BQ, Chu WW, Zhang LY, Wang P, Ma QY, Wang DH: Protection of preconditioning, postconditioning and combined therapy against hepatic ischemia/reperfusion injury. Chin J Traumatol 2007, 10:223-227.

17. Schofield CJ, Ratcliffe PJ: Oxygen sensing by HIF hydroxylases. NatRevMolCell Biol 2004, 5:343-354.

18. Lario S, Mendes D, Bescos M, Inigo P, Campos B, Alvarez R, Alcaraz A Rivera-Fillat F, Campistol JM: Expression of transforming growth factorbeta1 and hypoxia-inducible factor-1alpha in an experimental model of kidney transplantation. Transplantation 2003, 75:1647-1654.

19. Semenza G: Signal transduction to hypoxia-inducible factor 1. BiochemPharmacol 2002, 64:993-998.

20. Michalopoulos GK: Liver regeneration. JCell Physiol 2007, 213:286-300.

21. van der Bilt JD, Kranenburg O, Nijkamp MW, Smakman N, Veenendaal LM, Te Velde EA, Voest EE, van Diest PJ, Borel RI: Ischemia/reperfusion accelerates the outgrowth of hepatic micrometastases in a highly standardized murine model. Hepatology 2005, 42:165-175.

22. van der Bilt JD, Soeters ME, Duyverman AM, Nijkamp MW, Witteveen PO, van Diest PJ, Kranenburg O, Borel Rl: Perinecrotic hypoxia contributes to ischemia/reperfusion-accelerated outgrowth of colorectal micrometastases. AmJPathol 2007, 170:1379-1388.

23. Nicoud IB, Jones CM, Pierce JM, Earl TM, Matrisian LM, Chari RS, Gorden DL: Warm hepatic ischemia-reperfusion promotes growth of colorectal carcinoma micrometastases in mouse liver via matrix metalloproteinase9 induction. Cancer Res 2007, 67:2720-2728.

24. Carmeliet $P$, Jain RK: Angiogenesis in cancer and other diseases. Nature 2000, 407:249-257.

25. Drixler TA, Vogten MJ, Ritchie ED, van Vroonhoven TJ, Gebbink MF, Voest EE, Borel Rl: Liver regeneration is an angiogenesis- associated phenomenon. AnnSurg 2002, 236:703-711.

26. Los M, Voest EE, Borel Rl: VEGF as a target of therapy in gastrointestinal oncology. DigSurg 2005, 22:282-293.

27. Jensen $L$, Denner $L$, Schrijvers BF, Tilton RG, Rasch R, Flyvbjerg A: Renal effects of a neutralising RAGE-antibody in long-term streptozotocindiabetic mice. JEndocrinol 2006, 188:493-501.

28. Schmidt E, Schmidt FW: Enzyme diagnosis of liver diseases. Clin Biochem 1993, 26:241-251.

29. Scheig R: Evaluation of tests used to screen patients with liver disorders. Prim Care 1996, 23:551-560.

30. Giannini EG, Testa R, Savarino V: Liver enzyme alteration: a guide for clinicians. CMAJ 2005, 172:367-379.

31. Peralta C, Hotter G, Closa D, Gelpi E, Bulbena O, Rosello-Catafau J: Protective effect of preconditioning on the injury associated to hepatic ischemia-reperfusion in the rat: role of nitric oxide and adenosine. Hepatology 1997, 25:934-937.

32. Cursio R, Miele C, Filippa N, Van OE, Gugenheim J: Liver HIF-1 alpha induction precedes apoptosis following normothermic ischemiareperfusion in rats. TransplantProc 2008, 40:2042-2045.

33. Feinman $R$, Deitch EA, Watkins AC, Abungu B, Colorado I, Kannan KB, Sheth SU, Caputo FJ, Lu Q, Ramanathan M, et al: HIF-1 mediates pathogenic inflammatory responses to intestinal ischemia-reperfusion injury. Am J Physiol Gastrointest Liver Physiol 2010, 299:G833-843.

34. Wang YQ, Luk JM, Ikeda K, Man K, Chu AC, Kaneda K, Fan ST: Regulatory role of $\mathrm{vHL} / \mathrm{HIF}-1$ alpha in hypoxia-induced VEGF production in hepatic stellate cells. BiochemBiophysResCommun 2004, 317:358-362.

doi:10.1186/1476-5926-10-3

Cite this article as: Knudsen et al: Effects of ischemic pre- and postconditioning on HIF- $1 \alpha$, VEGF and TGF- $\beta$ expression after warm ischemia and reperfusion in the rat liver. Comparative Hepatology 2011 10:3.

\section{Submit your next manuscript to BioMed Central and take full advantage of:}

- Convenient online submission

- Thorough peer review

- No space constraints or color figure charges

- Immediate publication on acceptance

- Inclusion in PubMed, CAS, Scopus and Google Scholar

- Research which is freely available for redistribution

Submit your manuscript at www.biomedcentral.com/submit
CioMed Central 